\title{
Combining Systemic Therapies with Radiation in Non-Small Cell Lung Cancer Krzysztof Adamowicz*
}

Regional Oncology Center of Gdanskal, Poland

\begin{abstract}
Radiotherapy has been the mainstay of the treatment of stage III non-small cell lung cancer (NSCLC) patients. In the early nineties, combined treatment with chemotherapy was introduced. In 1995, a meta-analysis showed improved treatment outcome of the sequential use of cisplatin-based chemotherapy and radiotherapy (RCT) compared to radiotherapy alone. Subsequent randomized studies and the two meta-analyses demonstrated that concurrent radiochemotherapy (RCT) is superior (local control and overall survival) to sequential used both method. However, several questions remain unanswered concerning the optimal chemotherapy regimen and radiotherapy doses and techniques in terms of treatment outcome and toxicity profile. Targeted therapies represent a new class of drugs which interfere with specific molecular targets (typically proteins) playing critical roles in tumor growth and progression. Some combinations appear to be too toxic like the vascular epithelial growth factor antibody bevacizumab. The feasibility of adding the epidermal growth factor receptor inhibitor cetuximab has been recently reported for NSCLC patients. Strategies to safely incorporate novel antiangiogenic agents into combined-modality therapy in lung cancer are needed. The rapid development of molecular oncology will hopefully contribute to a better patient selection to particular strategies and to treatment optimization. Increasing radiotherapy doses applied according to up-to-date techniques and combinations with new biologicals might lead to further treatment improvements.
\end{abstract}

Keywords: Lung cancer; Chemotherapy; Radiotherapy

\section{Introduction}

Lung cancer is the most common cause of cancer death globally [1]. Most cases of lung cancer occur around the age of 60-70 years [2].

Treatment of non-small cell lung cancer (NSCLC) is challenging in many ways. Until the 1990s radiotherapy alone was the standard treatment for stages IIIA and IIIB non-small cell lung cancer (NSCLC). With the standard dose of $60 \mathrm{~Gy}$ in 30 fractions survival rates were extremely poor [3]. Indeed technical developments allowing the administration of higher radiation doses resulted in strategies to improve the treatment results include increasing doses of radiotherapy and decreasing overall treatment time [4]. For NSCLC a dose-effect relationship exists: the higher the radiation dose, the greater the probability of tumor control improved local control and survival [5]. The theoretical solution of simply increasing radiation doses to high biologically effective doses, ideally above the threshold of 100 Gy, has been suggested by several groups [6-9]. However, radiation dose escalation does not address the issue of distant or out-of-field relapses. A different option therefore is to combine radiotherapy with chemotherapy. The first report on improved survival after adding chemotherapy to the radiation was published more than 20 years ago [10]. Over the past decades, concomitant chemotherapy and radiotherapy has become the established treatment for patients with stage III non-small-cell lung cancer. In this review, we present current clinical knowledge on combining available systemic therapies with radiation.

\section{Radiochemotherapy in Locally Advanced Non-Small Cell Lung Cancer}

The strategy of exclusive radiotherapy for locally advanced inoperable NSCLC has been challenged after the publication of the meta-analysis by the Non-small Cell Lung Cancer Collaborative Group in 1995 [11]. Since then a combination of chemotherapy and radiotherapy is the recommended treatment in this group of patients. Radiotherapy preceded by (usually) two courses of chemotherapy yielded an improvement of the 2-year overall survival rate from $21 \%$ to $25 \%$. The 5 -year survival increased from $6 \%$ to $8 \%$ provided that the chemotherapy regimen included cisplatin. The effect was explained by a reduction of distant metastases. Until now this effect of a lower distant metastasis rate was observed in one study only [12]. In this study, Le Chevalier et al. compared radiotherapy alone to chemotherapy and radiotherapy. However, patients with adenocarcinoma were excluded. Since an important proportion of the NSCLC patients were not included, the results might not be representative. The 2-year survival rate was $14 \%$ in radiotherapy alone group and $21 \%$ in combined treatment group. The 3-year survival rate was $12 \%$ for the combination arm versus $4 \%$ for the radiotherapy arm $(\mathrm{P}<0.02)$ and local control was poor in both groups ( $17 \%$ and $15 \%$, respectively). To our knowledge, these results have never been confirmed. Until recently sequential cisplatin-containing radiochemotherapy has been the standard treatment for inoperable stage IIIA and IIIB disease. Various chemotherapy schedules have been applied, but the treatment outcome did not differ significantly.

Despite this progress, both loco-regional and distant failures are frequent. Over the last 20 years, concomitant use of radiotherapy and chemotherapy has been extensively studied in various malignancies, including non-small cell lung cancer, rectal cancer, anal cancer and head and neck cancers, and has currently replaced radiotherapy alone in patients with good performance status. This strategy, through superadditive effect, not only improves local tumor control but

*Corresponding author: Krzysztof Adamowicz, Regional Oncology Center of Gdanskal. Zwyciestwa 32, 80-219 Gdansk, Poland, Tel: +48 5873248 01; Fax: +48 5873248 03; E-mail: krzys.adamowicz@gmail.com

Received February 11, 2015; Accepted March 30, 2015; Published April 02, 2015

Citation: Adamowicz K (2015) Combining Systemic Therapies with Radiation in Non-Small Cell Lung Cancer. J Cancer Sci Ther 7: 102-110. doi:10.4172/19485956.1000332

Copyright: ( 2015 Adamowicz K. This is an open-access article distributed under the terms of the Creative Commons Attribution License, which permits unrestricted use, distribution, and reproduction in any medium, provided the original author and source are credited. 
also increases the overall survival [13]. The benefits of concomitant radiochemotherapy include a potential synergism between both modalities and avoiding the delay of radiotherapy. Therefore, there is a rationale for considering concomitant chemo-radiation also in patients with high-risk lung cancer. Attempts to improve the locoregional control included increasing the radiotherapy dose using altered fractionation regiments and combining chemotherapy with radiotherapy. After phase I and phase II studies, the EORTC started a 3-arm phase III trial comparing split-course radiotherapy of 55Gy using the same radiotherapy scheme, concurrently combined with 30 $\mathrm{mg} / \mathrm{m}^{2}$ cisplatin once a week or $6 \mathrm{mg} / \mathrm{m}^{2}$ daily [14]. No improvement was seen after treatment with radiotherapy and weekly cisplatin. The 6 $\mathrm{mg} / \mathrm{m}^{2}$ cisplatin daily added to radiotherapy improved survival due to improved control of local disease. The difference was also significant after adjustment for known prognostic factors in a multivariate analysis. There was no effect on the distant metastasis rate, and late toxicity was not increased. These data demonstrated that cisplatin improved the radiotherapy effect by radiosensitization. The most frequently reported acute side effects were nausea and vomiting. In 1992, Trovo et al. [15] also published their randomized phase III study. Three weeks of radiotherapy, to a dose $45 \mathrm{~Gy}$, were compared to the same radiotherapy dose with the addition of $6 \mathrm{mg} / \mathrm{m}^{2}$ cisplatin daily. In this study no significant advantage of the combined treatment over radiation therapy only was found. However, this result may be due to the lower dosage of radiation used in the study (Table 1).

All phase III trials were included in a meta-analysis including 12 trials and 1921 patients by Aupérin et al. [16] indicated a 4\% survival gain at 2 years and $2 \%$ at 5 years for concurrent chemoradiation versus radiotherapy alone, a comparable improvement to that observed with the sequential combination. Even though this meta-analysis was based on individual patient data it did not allow to accurately define the size of such a potential treatment benefit and the optimal schedule

\begin{tabular}{|c|c|c|c|c|c|}
\hline $\begin{array}{l}\text { Reference } \\
\text { (therapy) }\end{array}$ & Study type & Patients & RT schedule & Systemic therapy & Results \\
\hline $\begin{array}{l}\text { Le Chevalier } \\
\text { et al. [12] }\end{array}$ & $\begin{array}{l}\text { phase III, } \\
\mathrm{n}=353\end{array}$ & $\begin{array}{l}\text { nonresectable squamous } \\
\text { cell and large-cell lung } \\
\text { carcinoma; WHO 0-1; } \\
\text { stage IIIA or IIIB, }\end{array}$ & $\begin{array}{l}\text { the radiation dose was } \\
65 \mathrm{~Gy} \text { in each group }\end{array}$ & $\begin{array}{l}\text { radiotherapy alone (group A), combined } \\
\text { treatment (group B) + CT included vindesine, } \\
\text { cyclophosphamide, cisplatin, and lomustine }\end{array}$ & $\begin{array}{l}\text { 2-year survival rate was } 14 \% \text { in group A } \\
\text { and } 21 \% \text { in group B } \\
\text { distant metastasis rate was significantly } \\
\text { lower in group B } \\
\text { local control was poor in both groups } \\
(17 \% \text { and } 15 \%)\end{array}$ \\
\hline $\begin{array}{l}\text { Schaake- } \\
\text { Koning et al. } \\
{[14]}\end{array}$ & $\begin{array}{l}\text { phase III, } \\
n=100\end{array}$ & $\begin{array}{l}\text { inoperable stage I, II, or III; } \\
\text { no more than } 70 \text { years old; } \\
\text { medical contraindications } \\
\text { to operation; ECOG 0-2; } \\
\text { creatinine clearance min. } \\
70 \text { ml per minute. }\end{array}$ & $\begin{array}{l}\text { radiation was } \\
\text { administered for two } \\
\text { weeks in a dose of } \\
3 \text { Gy given } 10 \text { times, } \\
\text { followed by a rest } \\
\text { period of three weeks; } \\
\text { radiation was again } \\
\text { administered for two } \\
\text { weeks in a dose of } 2.5 \\
\text { Gy given } 10 \text { times, }\end{array}$ & $\begin{array}{l}\text { radiotherapy alone (group A); radiotherapy } \\
\text { combined with cisplatin in a dose of } 30 \mathrm{mg} / \\
\mathrm{m} 2 \text {, given intravenously on day } 1 \text { of each } \\
\text { treatment week (group B); radiotherapy with } \\
\text { cisplatin in a dose of } 6 \mathrm{mg} / \mathrm{m} 2 \text { daily (group C) }\end{array}$ & $\begin{array}{l}\text { Survival was significantly improved in the } \\
\text { group C as compared with the group A; } \\
\text { survival in group C was } 54 \text { percent at } \\
\text { one year, } 26 \text { percent at two years, and } \\
16 \text { percent at three years, as compared } \\
\text { with } 46 \text { percent, } 13 \text { percent, and } 2 \\
\text { percent in group A. } \\
\text { Survival in group B was intermediate ( } 44 \\
\text { percent, } 19 \text { percent, and } 13 \text { percent) and } \\
\text { not significantly different from survival in } \\
\text { either of the other two groups. percent } \\
\text { and } 28 \text { percent, respectively. }\end{array}$ \\
\hline $\begin{array}{l}\text { Trovo et al. } \\
{[15]}\end{array}$ & $\begin{array}{l}\text { phase III, } \\
n=173\end{array}$ & inoperable, stage III & $\begin{array}{l}\mathrm{RT} 45 \mathrm{~Gy} / 15 \\
\text { fractions/3 weeks }\end{array}$ & $\begin{array}{l}\text { only RT (arm A) versus RT and daily cisplatin } \\
\text { dose } 6 \mathrm{mg} / \mathrm{m} 2(\operatorname{arm~B})\end{array}$ & $\begin{array}{l}\text { median TTP was } 10.6 \text { mo for arm A and } \\
14.2 \text { mo for arm } B \text {. } \\
\text { Median survivals: } 10.3 \text { mo and } 9.97 \text { mo } \\
\text { no significant advantage of the combined } \\
\text { treatment over radiation therapy only } \\
\text { was found }\end{array}$ \\
\hline $\begin{array}{l}\text { Aupérin et al. } \\
\text { [16] }\end{array}$ & $\begin{array}{l}\text { meta- } \\
\text { analysis } \\
n=1764\end{array}$ & $\begin{array}{l}\text { inoperable stage I, II, III } \\
\text { and IV; ECOG 0-3; }\end{array}$ & $\begin{array}{l}\text { RT } 45 G Y \text { to } \\
69.6 \mathrm{GY} / 15- \\
\text { 58fractions/3-6weeks }\end{array}$ & $\begin{array}{l}\text { nine randomised studies } \\
\text { only RT (arm A) and RT with CT(arm B) } \\
\text { (cisplatin daily, cisplatin weekly, carboplatin, } \\
\text { cisplatin+etoposide; carboplatin+etoposide); }\end{array}$ & $\begin{array}{l}\text { the hazard ratio of death in } \\
\text { arm B to arm A } 0.89 \\
\text { absolute benefit of CT } 4 \% \text { at } 2 \text { years and } \\
2.2 \% \text { at } 5 \text { yearg, } \\
\text { 2- and } 5 \text {-year survival rates from } 21.4 \% \\
(\text { arm A) to } 25.4 \% \text { (arm B), and from } \\
6.0 \%(\operatorname{arm~A)~to~} 8.2 \%(\text { arm B) }\end{array}$ \\
\hline $\begin{array}{l}\text { Rowell et al. } \\
{[17]}\end{array}$ & $\begin{array}{l}\text { meta- } \\
\text { analysis } \\
n=2393\end{array}$ & $\begin{array}{l}\text { inoperable stage I, II, III; } \\
\text { ECOG 0-3; }\end{array}$ & $\begin{array}{l}\text { RT } 45 G Y \text { to } \\
69.6 G Y / 15- \\
\text { 58fractions/3-6weeks }\end{array}$ & $\begin{array}{l}\text { fourteen randomised studies } \\
\text { only RT (arm A) and RT with CT(arm B) } \\
\text { (cisplatin daily, cisplatin weekly, carboplatin, } \\
\text { cisplatin+etoposide; NR); }\end{array}$ & 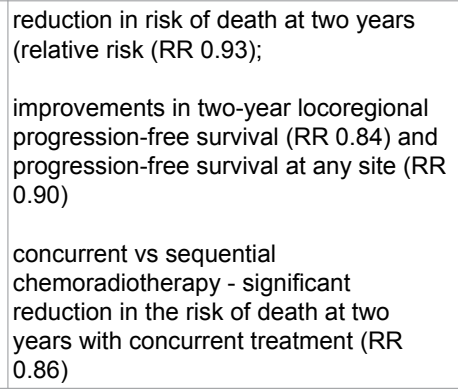 \\
\hline
\end{tabular}




\begin{tabular}{|c|c|c|c|c|c|}
\hline $\begin{array}{l}\text { Aupérin et al. } \\
\text { [24] }\end{array}$ & $\begin{array}{l}\text { meta- } \\
\text { analysis } \\
n=1205\end{array}$ & $\begin{array}{l}\text { inoperable stage I, II, III } \\
\text { and IV; ECOG 0-2; }\end{array}$ & $\begin{array}{l}\text { RT } 60 \text { and } 66 \text { Gy in } \\
\text { two trial each, and } \\
56 \text { and } 48.5 \text { Gy in } \\
\text { one trial each. In one } \\
\text { trial the radiotherapy } \\
\text { - different in the two } \\
\text { arms-there was a } \\
10 \text { days split in the } \\
\text { concomitant arm. } \\
\text { In the five trials } \\
\text { in the sequential } \\
\text { arm, patients } \\
\text { randomly assigned } \\
\text { to concomitant arm } \\
\text { received radiotherapy } \\
\text { more frequently } \\
\text { than those randomly } \\
\text { assigned to the } \\
\text { sequential arm, }\end{array}$ & $\begin{array}{l}\text { eleven randomised studies } \\
\text { sequential -cisplatin combined with one drug } \\
\text { in four trials, or with two drugs in two trials. } \\
\text { Vinorelbine or gemcitabine were used in two } \\
\text { trials. } \\
\text { concomitant radiochemotherapy arm, cisplatin } \\
\text { was used in five trials, either on a daily basis } \\
\text { as single agent (two trials) or combined with } \\
\text { other drugs every } 4 \text { weeks (three trials). } \\
\text { Carboplatin administered weekly was used in } \\
\text { only one trial. }\end{array}$ & $\begin{array}{l}\text { OS: significant benefit of concomitant } \\
\text { radiochemotherapy (HR, } 0.84 \text { ) with an } \\
\text { absolute benefit of } 5.7 \% \text { (from } 18.1 \% \text { to } \\
23.8 \% \text { ) at } 3 \text { years and } 4.5 \% \text { at } 5 \text { years. } \\
\text { PFS: significant benefit of concomitant } \\
\text { radiochemotherapy HR was } 0.90 \\
\text { Concomitant treatment decreased } \\
\text { locoregional progression (HR, } 0.77 \text { ); } \\
\text { Concomitant radiochemotherapy } \\
\text { increased acute esophageal toxicity } \\
\text { (grade 3-4) from } 4 \% \text { to } 18 \%\end{array}$ \\
\hline $\begin{array}{l}\text { O'Rourke et } \\
\text { al. [25] } \\
\text { RT vs RT } \\
\text { and CT }\end{array}$ & $\begin{array}{l}\text { meta- } \\
\text { analysis } \\
n=2728\end{array}$ & $\begin{array}{l}\text { inoperable stage I, II, III; } \\
\text { ECOG 0-3; }\end{array}$ & $\begin{array}{l}\text { RT } 56 \mathrm{~Gy} / 28 \text { fractions- } \\
70.2 \mathrm{~Gy} / 39 \text { fractions }\end{array}$ & $\begin{array}{l}\text { nineteen randomised studies } \\
\text { vindesine/cisplatin/mitomycin C; cisplatin/ } \\
\text { vinblastine; cisplatin/ vinorelbine; carboplatin/ } \\
\text { paclitaxel }\end{array}$ & $\begin{array}{l}\text { Chemoradiotherapy reduced overall risk } \\
\text { of death (HR 0.71) and PFS (HR 0.69) } \\
\text { Incidence of acute oesophagitis, } \\
\text { neutropenia and anaemia were } \\
\text { significantly increased with concurrent } \\
\text { chemoradiation. }\end{array}$ \\
\hline $\begin{array}{l}\text { O'Rourke et } \\
\text { al. [25] } \\
\text { sequential } \\
\text { RT and } \\
\text { CT vs } \\
\text { concomitant } \\
\text { RT and CT }\end{array}$ & $\begin{array}{l}\text { meta- } \\
\text { analysis } \\
n=1024\end{array}$ & $\begin{array}{l}\text { inoperable stage I, II, III; } \\
\text { ECOG 0-3; }\end{array}$ & $\begin{array}{l}\text { RT- } 56 \text { Gy/28 } \\
\text { fractions- } 70.2 \text { Gy/39 } \\
\text { fractions }\end{array}$ & $\begin{array}{l}\text { six randomised trials } \\
\text { vindesine/cisplatin/mitomycin C; cisplatin/ } \\
\text { vinblastine; cisplatin/ vinorelbine; carboplatin/ } \\
\text { paclitaxel }\end{array}$ & $\begin{array}{l}\text { OS: significant benefit of concurrent } \\
\text { treatment (HR 0.74) with } 10 \% \text { absolute } \\
\text { survival benefit at } 2 \text { years. } \\
\text { More treatment-related deaths ( } 4 \% \\
\text { vs } 2 \% \text { ) in the concurrent arm without } \\
\text { statistical significance (RR } 2.02 \text { ) } \\
\text { increased esophagitis with concurrent } \\
\text { treatment (RR 4.96). }\end{array}$ \\
\hline
\end{tabular}

RT: radiotherapy; IMRT: intensity-modulated radiotherapy; CT: chemotherapy; KPS: Karnofsky performance status; ECOG: Eastern Cooperative Oncology Group performance status; WHO: World Health Organisation performance status; ENI: elective nodal irradiation;

OS: overall survival; PFS: progression-free survival; PR and CR: partial and complete remission; TTP: time to progresion; NR: not reported;

Table 1: Chemoradiotherapy in locally advanced non-small cell lung cancer.

of chemotherapy. The efficacy of concurrent chemoradiotherapy versus radiotherapy also was compared in a metaanalysis including 14 randomized studies (and 2393 patients) in 2010 [17]. A Cochrane metaanalysis confirmed these conclusions: concurrent chemoradiotherapy was associated with $14 \%$ reduction in the risk of death at 2 years compared to sequential chemoradiotherapy, and a $7 \%$ reduction compared to radiotherapy alone.

If sequential and concurrent radiochemotherapy improved overall survival, so there is another question: which is better? In several trials improved 1- and 2-year overall survival rates in favour of the concurrent arm were reported [18-23]. Most of these trials were included in a new meta-analysis based on individual patient data by Aupérin et al. [24] concluded that concurrent radiochemotherapy yielded superior results compared to the sequential combinations. There was a significant benefit of concomitant radiochemotherapy on overall survival $(\mathrm{P}=0.004)$, with an absolute benefit of $5.7 \%$ (from $18.1 \%$ to $23.8 \%$ ) at 3 years and $4.5 \%$ at 5 years. There was no significant difference regarding acute pulmonary toxicity. Concomitant treatment decreased locoregional progression, but concomitant radiochemotherapy increased acute esophageal toxicity (grade $3-4$ ) from $4 \%$ to $18 \%$. This improved survival was accomplished because of an improved locoregional control. There were no significant differences between the regimens: single or double high-dose chemotherapy or daily low-dose cisplatin. No differences in distant metastasis rate were observed between the two approaches.

Within a few months a meta-analysis was published by O'Rourke et al. [25] reporting a $10 \%$ absolute survival benefit at two years. Six trials
(1024 patients) of concurrent versus sequential chemoradiation were included. A significant benefit of concurrent treatment was shown in overall survival (hazard ratio-HR $0.74,95 \%$ CI 0.62 to 0.89 ). More treatment-related deaths ( $4 \%$ vs $2 \%$ ) were reported in the concurrent arm without statistical significance (Relative Risk-RR 2.02, 95\% CI 0.90 to 4.52 ). There was increased severe esophagitis with concurrent treatment (RR $4.96,95 \% \mathrm{CI} 2.17$ to 11.37 ). The most important acute but manageable side effect was esophagitis grade 3 to 4 in $18 \%$ of the patients treated with concurrent radiochemotherapy versus $4 \%$ in the patients treated with sequential arm.

The role of timing and sequencing the treatment may also depend on the tumor type, the degree of oxygenation of tumor cells and other biochemical processes occurring during radiation. In clinical practice, a compromise option is the alternation of radiotherapy and chemotherapy, for example by insertion of radiotherapy after 2-3 cycles of chemotherapy. The clinical efficacy of this strategy has, however, not been verified in prospective clinical studies. Concurrent chemoradiation is at present the treatment of choice for patients with locally advanced NSCLC. However, due to its higher toxicity, this combination is mostly restricted to patients in a good general condition, minimal comorbidity and who are relatively young [2629]. There is a question what proportion of patients would be suitable for concurrent chemoradiation. We found only one report on a population-based study that prospectively evaluated comorbidities in all patients diagnosed with lung cancer, stage III for NSCLC [30]. In this prospective, population-based study, more than half of the patients with stage III NSCLC were not eligible for concurrent chemoradiation 
on the basis of criteria of age and important comorbidities that were present at diagnosis. Less toxic alternatives are needed for these patients. So, there are arguments for sequential treatment like "safe" delivery of full dose of radiotherapy and chemotherapy, but there are also problems like delayed radiotherapy delivery especially in patients' slow recovery from chemotherapy. El Sharouni [31] shows that in the time interval between the end of induction chemotherapy and the start of radiotherapy rapid tumor progression occurs as a result of accelerated tumor cell proliferation: mean tumor doubling times are much shorter than those in not treated tumors. As a consequence, the gain obtained with induction chemotherapy with regard to volume reduction was lost in the waiting time for radiotherapy (chemoresistant stem cells that persist and can give rise to tumor regrowth). A correlation was observed between the amount of delay and degree of regrowth for percent volume and percent tumor diameter change. A delay between induction chemotherapy and radiotherapy greater than 21 days produced greater increases in percent volume change and percent diameter than lesser delays [32]. Also a retrospective analysis of a total of 474 patients demonstrates a correlation between prolonged overall radiotherapy treatment time and survival in patients with locally advanced NSCLC, even when concurrent chemotherapy is used [33]. It is recommend diminishing the time interval between chemoand radiotherapy to as short as possible.

\section{Targeted Therapies and Radiotherapy in Locally Advanced Non-Small Cell Lung Cancer}

Targeted therapies represent a new class of drugs which interfere with specific molecular targets (typically proteins) playing critical roles in tumor growth and progression. The approved targeted therapies in lung cancer include erlotinib, gefitinib (a small-molecule tyrosine kinase inhibitor) and bevacizumab (a monoclonal anti-VEGF antibody). The accepted dogma is that antiangiogenic therapy destroys or blocks the function of tumor-associated vessels to deprive the tumor of oxygen and nutrients, thereby inhibiting tumor growth. Numerous preclinical studies indicated synergistic activity of various antiangiogenic or antivascular therapies with single-dose or fractionated radiotherapy in human and murine tumors $[34,35]$. However, since multiple variables contribute to the sensitivity of tumors to radiation or antiangiogenic treatment, the most effective way of their combining is virtually unknown [36,37]. Blocking survival signalling in endothelial cells after irradiation seems to increase the radiation response considerably [38]. Moreover, sensitization of endothelial cells just before exposure to radiation may be the most effective way to improve response of tumor cells to radiation $[39,40]$. On the other hand, induction of hypoxia via blood vessel damage may potentially induce radioprotection of the tumor. A logical and clearly proven premise for optimal multimodality therapy is therefore necessary for efficient translation of promising preclinical strategies into clinical applications. Many new biologicals have entered the therapeutic domain, several were combined with concurrent RCT regimens. Some combinations appear to be too toxic like the vascular epithelial growth factor antibody bevacizumab [41] Also, the use of bevacizumab and erlotinib is not recommended given the lack of an efficacy signal and the substantial risk of esophageal toxicity [42] (Table 2).

\begin{tabular}{|c|c|c|c|c|c|}
\hline Reference (therapy) & Study type & Patients & RT schedule & Systemic therapy & Results \\
\hline $\begin{array}{l}\text { Spigel et al. [41] } \\
\text { bevacizumab }\end{array}$ & $\begin{array}{l}\text { phase II } \\
n=29 \text { (small cel) } \\
n=5 \text { non-small } \\
\text { cell }\end{array}$ & $\begin{array}{l}\text { non-small-cell } \\
\text { lung cancer trial } \\
\text { included patients with } \\
\text { unresectable stage III } \\
\text { nonsquamous without } \\
\text { pleural or pericardial } \\
\text { effusions; ECOG 0-1; }\end{array}$ & $\begin{array}{l}\text { RT began with cycle } \\
\text { 3, at a dose of } 1.8 \\
\text { Gy/d to a total of } \\
61.2 \mathrm{~Gy}\end{array}$ & $\begin{array}{l}\text { induction treatment included: carboplatin AUC = } 5 \text {, } \\
\text { pemetrexed } 500 \mathrm{mg} / \mathrm{m} 2 \text {, and bevacizumab } 15 \mathrm{mg} / \mathrm{kg} \text {; } \\
\text { consolidative therapy with carboplatin AUC = } 6, \\
\text { pemetrexed } 500 \mathrm{mg} / \mathrm{m} 2 \text {, and bevacizumab } 15 \mathrm{mg} / \mathrm{kg} \\
\text { patients received maintenance bevacizumab } 15 \mathrm{mg} / \\
\mathrm{kg} \text { every } 3 \text { weeks for } 9 \text { cycles with restaging every } \\
3 \text { months }\end{array}$ & $\begin{array}{l}\text { the trial's primary PFS } \\
\text { end point could not be } \\
\text { assessed due to early trial } \\
\text { closure becouse of toxicity. } \\
\text { the objective response rate } \\
\text { was } 88 \% \\
\text { two patients developed } \\
\text { tracheoesophageal } \\
\text { fistulae, prompting early } \\
\text { study closure. Both } \\
\text { patients developed } \\
\text { esophageal toxicity during } \\
\text { chemoradiotherapy and } \\
\text { bevacizumab treatment. }\end{array}$ \\
\hline $\begin{array}{l}\text { Socinski et al. [42] } \\
\text { bevacizumab }\end{array}$ & phase I/II & $\begin{array}{l}\text { medically inoperable } \\
\text { or unresectable, WHO } \\
0-1 ; \text { stage IIIA or IIIB, }\end{array}$ & $\begin{array}{l}\text { conformal radiation } \\
\text { therapy to } 74 \mathrm{~Gy}\end{array}$ & $\begin{array}{l}\text { induction chemotherapy (carboplatin AUC } 6 \text {, } \\
\text { paclitaxel } 225 \mathrm{mg} / \mathrm{m} 2 \text {, and bevacizumab } 15 \mathrm{mg} / \mathrm{kg} \\
\text { followed by concurrent chemotherapy (carboplatin } \\
\text { AUC } 2 \text { and paclitaxel } 45 \mathrm{mg} / \mathrm{m} 2 \text { weekly with } \\
\text { bevacizumab } 10 \mathrm{mg} / \mathrm{kg} \text { In the phase I portion, cohort } \\
1 \text { received no erlotinib, whereas cohorts } 2 \text { and } 3 \\
\text { received erlotinib at } 100 \text { and } 150 \mathrm{mg} \text {, respectively. } \\
\text { consolidation therapy with erlotinib ( } 150 \mathrm{mg} \text { daily) } \\
\text { and bevacizumab (15 mg/kg every } 3 \text { weeks) } 3 \text { to } 6 \\
\text { weeks later for } 6 \text { cycles }\end{array}$ & $\begin{array}{l}\text { the objective response } \\
\text { rates to induction and } \\
\text { overall treatment were } \\
39 \% \text { and } 60 \% \text {. } \\
\text { median PFS } 10.2 \text { mo } \\
\text { median OS } 18.4 \text { mo }\end{array}$ \\
\hline $\begin{array}{l}\text { Kelly et al. [44] } \\
\text { gefitinib }\end{array}$ & $\begin{array}{l}\text { phase III } \\
n=243\end{array}$ & $\begin{array}{l}\text { inoperable stage IIIA } \\
\text { or IIIB without pleural } \\
\text { or pericardial effusions; } \\
\text { ECOG 0-1; }\end{array}$ & $\begin{array}{l}\text { initial field received } \\
1.8 \mathrm{~Gy} / \mathrm{d} \text { for } 5 \\
\text { weeks for a dose of } \\
45 \mathrm{~Gy} \text {; an additional } \\
\text { radiation boost } \\
\text { to gross disease } \\
\text { with } 2 \text { Gy/d to } 16 \\
\text { Gy was delivered } \\
\text { without a break. } \\
\text { The total radiation } \\
\text { dose received was } \\
61 \text { Gy. }\end{array}$ & $\begin{array}{l}\text { concurrent cisplatin and etoposide with thoracic } \\
\text { radiation. cisplatin } 50 \mathrm{mg} / \mathrm{m} 2 \text { with etoposide } 50 \mathrm{mg} / \\
\mathrm{m} 2 . \\
4 \text { to } 8 \text { weeks after completion of radiation, patients } \\
\text { without progressive disease received } 3 \text { cycles of } \\
\text { docetaxel } 75 \mathrm{mg} / \mathrm{m} 2 \\
3 \text { to } 6 \text { weeks after docetaxel, patients received } \\
\text { gefitinib } 500 \mathrm{mg} \text { or placebo orally, once a day for } \\
5 \text { years or until disease progression or intolerable } \\
\text { toxicity. Later gefitinib was amended to the } 250 \mathrm{mg} / \mathrm{d}\end{array}$ & $\begin{array}{l}\text { median survival time was } \\
23 \text { months for gefitinib ( } \mathrm{n} \\
=118 \text { ) and } 35 \text { months for } \\
\text { placebo } \\
\text { the toxic death rate was } \\
2 \% \text { with gefitinib compared } \\
\text { with } 0 \% \text { for placebo. }\end{array}$ \\
\hline
\end{tabular}


Citation: Adamowicz K (2015) Combining Systemic Therapies with Radiation in Non-Small Cell Lung Cancer. J Cancer Sci Ther 7: 102-110. doi:10.4172/1948-5956.1000332

\begin{tabular}{|c|c|c|c|c|c|}
\hline $\begin{array}{l}\text { Martinez et al. [52] } \\
\text { erlotinib }\end{array}$ & $\begin{array}{l}\text { phase II } \\
n=23\end{array}$ & $\begin{array}{l}\text { unresectable stage } \\
\text { I-IIIA, not suitable to } \\
\text { receive chemotherapy, } \\
\text { ECOG } 0 \text { - } 2\end{array}$ & $\begin{array}{l}66 \text { Gy in } 33 \\
\text { fractions during } 6 \\
\text { weeks }\end{array}$ & $\begin{array}{l}\mathrm{RT} \text { and placebo (arm a) or concomitant erlotinib } 150 \\
\mathrm{mg} / \text { day po maintained for } 6 \text { months (arm b) }\end{array}$ & $\begin{array}{l}\text { esophagitis } 40 \% \text { in arm } \\
\text { A and } 23 \% \text { in arm B, (no } \\
\text { grade } 3-4 \text { ). } \\
\text { radiodermitis } 50 \% \text { in arm } \\
\text { A (no grade } 3-4 \text { observed) } \\
\text { and } 8 \% \text { in arm B, being } \\
\text { grade } 3 . \\
\text { pneumonitis } 20 \% \text { in arm } \\
\text { A ( } 10 \% \text { grade } 3 \text { ) and } 8 \% \\
\text { in arm B (no grade } 3-4 \\
\text { observed). } \\
\text { main toxicities related to } \\
\text { erlotinib were skin rash } \\
(61.5 \% \text { ) and diarrhea } \\
(23 \%) \\
\text { response rate in arm A } \\
\text { was } 55.5 \% \text { and } 83.3 \% \\
\text { in arm B. Disease } \\
\text { progression is documented } \\
\text { in } 22.2 \% \text { in arm A and } \\
16.7 \% \text { in arm B }\end{array}$ \\
\hline $\begin{array}{l}\text { Jensen et al. [57] } \\
\text { cetuximab }\end{array}$ & $\begin{array}{l}\text { phase II } \\
n=30\end{array}$ & $\begin{array}{l}\text { not candidates } \\
\text { for concomitant } \\
\text { chemoradiation (or } \\
\text { refused), KPS at least } \\
70 \text {, one of two trials } \\
\text { with mandatory PET; } \\
\text { stage IIIA or IIIB, no } \\
\text { malignant pleural } \\
\text { effusion, }\end{array}$ & $\begin{array}{l}\text { IMRT trial, } 66 \text { Gy in } \\
33 \text { daily fractions of } \\
2 \text { Gy, ENI to } 50 \text { Gy } \\
\text { (or } 40 \text { depending on } \\
\text { lung dose) }\end{array}$ & $\begin{array}{l}\text { cetuximab followed by } 13 \text { weekly consolidation } \\
\text { cycles }\end{array}$ & $\begin{array}{l}\text { median OS } 19.6 \mathrm{mo}, \\
\text { median PFS } 8.5 \mathrm{mo}, 63 \% \\
\text { PR, no CR, }\end{array}$ \\
\hline $\begin{array}{l}\text { Jatoi et al. [56] } \\
\text { Cetuximab }\end{array}$ & $\begin{array}{l}\text { phase II, } \\
n=58\end{array}$ & $\begin{array}{l}\text { not candidates } \\
\text { for concomitant } \\
\text { chemoradiation, either } \\
\text { age } \geq 65 \text { years with } \\
\text { ECOG } 0-2 \text { or younger } \\
\text { but ECOG 2; stage } \\
\text { IIIA or IIIB, no pleural } \\
\text { effusion, }\end{array}$ & $\begin{array}{l}\text { RT } 60 \text { Gy in } 30 \\
\text { daily fractions } \\
\text { of } 2 \text { Gy, ENI to } \\
\text { ipsilateral hilar and } \\
\text { mediastinal nodes } \\
\text { (44 Gy) }\end{array}$ & $\begin{array}{l}\text { cetuximab } 400 \mathrm{mg} / \mathrm{m}(2) \text { i.v. on day } 1 \text { followed by } \\
\text { weekly cetuximab } 250 \mathrm{mg} / \mathrm{m}(2) \text { i.v. with concomitant } \\
\text { radiation }\end{array}$ & $\begin{array}{l}\text { median OS } 15.1 \mathrm{mo} \text {, } \\
\text { median PFS } 7.2 \mathrm{mo}, 26 \% \\
\text { PR, no CR }\end{array}$ \\
\hline $\begin{array}{l}\text { Hallqvist et al. [58] } \\
\text { cetuximab }\end{array}$ & $\begin{array}{l}\text { phase II, } \\
\mathrm{n}=71\end{array}$ & $\begin{array}{l}\text { medically inoperable } \\
\text { or unresectable, WHO } \\
0-1 ; \text { stage IIIA or IIIB, } \\
\text { no pleural effusion with } \\
\text { positive cytology, }\end{array}$ & $\begin{array}{l}\text { RT } 68 \text { Gy in } 34 \\
\text { daily fractions of } 2 \\
\text { Gy, no ENI }\end{array}$ & $\begin{array}{l}2 \text { cycles of induction cisplatin/docetaxel, cetuximab } \\
\text { starting one week before RT }\end{array}$ & $\begin{array}{l}\text { median OS } 17 \text { mo, PFS } \\
\text { NR, } 16 \% \text { PR and } 7 \% \text { CR } \\
\text { at } 12 \text { months (NR at earlier } \\
\text { time points), patterns } \\
\text { of failure: } 31 \% \text { distant } \\
\text { only, } 23 \% \text { local only, } \\
7 \% \text { regional only, } 11 \% \\
\text { combinations of these, }\end{array}$ \\
\hline $\begin{array}{l}\text { Hughes et al. [59] } \\
\text { cetuximab }\end{array}$ & $\begin{array}{l}\text { phase II, } \\
n=12\end{array}$ & $\begin{array}{l}\text { Inoperable, WHO 0-1; } \\
\text { Stage IIIA or B, no } \\
\text { pleural effusion }\end{array}$ & $\begin{array}{l}\text { RT } 64 \text { Gy in } 32 \\
\text { fractions of } 2 \text { Gy, } \\
\text { in } 4 \text { cases ENI to } \\
\text { ipsilateral hilar and } \\
\text { mediastinal nodes } \\
\text { (50 Gy) }\end{array}$ & $\begin{array}{l}\text { up to } 4 \text { cycles (median } 3 \text { ) of platinum-based induction } \\
\text { CT, cetuximab starting one week before RT }\end{array}$ & $\begin{array}{l}\text { median OS NR, PFS NR, } \\
58 \% \text { PR, no CR, }\end{array}$ \\
\hline $\begin{array}{l}\text { Blumenschein et al. } \\
{[60]} \\
\text { cetuximab }\end{array}$ & $\begin{array}{l}\text { phase II, } \\
n=87\end{array}$ & $\begin{array}{l}\text { Inoperable, Zubrod } 0-1 \text {; } \\
\text { Stage IIIA or B, weight } \\
\text { loss }<5 \%, \text { FEV1 } \geq 1,2 \text { I }\end{array}$ & $\begin{array}{l}\text { RT } 63 \text { Gy in } \\
35 \text { fractions of } \\
1.8 \text { Gy, ENI to } \\
\text { ipsilateral hilar and } \\
\text { mediastinal nodes } \\
\text { (45 Gy) }\end{array}$ & $\begin{array}{l}\text { cetuximab week } 1-17 \text {, weekly carboplatin/paclitaxel } \\
\text { during RT followed by } 2 \text { cycles consolidation } \\
\text { carboplatin/paclitaxel }\end{array}$ & $\begin{array}{l}\text { median OS } 22.7 \text { mo, } \\
\text { median time to progression } \\
\text { around } 14-15 \text { mo, } 29 \% \\
\text { CR, } 33 \% \text { PR, }\end{array}$ \\
\hline $\begin{array}{l}\text { Govindan et al. [61] } \\
\text { cetuximab }\end{array}$ & $\begin{array}{l}\text { phase II, } \\
n=101\end{array}$ & $\begin{array}{l}\text { Inoperable, ECOG } 0-1 \text {, } \\
\text { one of two trials with } \\
\text { mandatory PET; Stage } \\
\text { IIIA or B, no pleural } \\
\text { effusion, weight loss } \\
\leq 10 \%\end{array}$ & $\begin{array}{l}70 \text { Gy in } 35 \\
\text { fractions of } 2 \text { Gy, } \\
\text { no ENI }\end{array}$ & $\begin{array}{l}\text { cetuximab }(7 \text { weeks) plus } 4 \text { cycles carboplatin/ } \\
\text { pemetrexed vs. CT without cetuximab }(n=48) \text {, } \\
\text { afterwards } 4 \text { cycles of pemetrexed }\end{array}$ & $\begin{array}{l}\text { median OS } 25.2 \mathrm{mo} \text {, } \\
\text { median failure-free survival } \\
12.3 \mathrm{mo}, 4 \% \mathrm{CR}, 68 \% \mathrm{PR} \text {, }\end{array}$ \\
\hline
\end{tabular}

RT: radiotherapy; IMRT: intensity-modulated radiotherapy; CT: chemotherapy; KPS: Karnofsky performance status; ECOG: Eastern Cooperative Oncology Group performance status; WHO: World Health Organisation performance status; ENI: elective nodal irradiation;

OS: overall survival; PFS: progression-free survival; PR and CR: partial and complete remission; NR: not reported; PET: positron emission tomography

Table 2: Targeted therapies and radiotherapy in locally advanced non-small cell lung cancer. 
Erlotinib and gefitinib are a small molecule inhibitor that reversibly targets the tyrosine kinase activity of the epidermal growth factor receptor (EGFR). EGFR is overexpressed and/or mutated in many cancer types, and its activation triggers pathways involved in cell growth and proliferation. Early clinical studies with gefitinib showed promising efficacy and mild toxicity in patients with advanced non-small-cell lung cancer (NSCLC). In clonogenic in vitro survival experiments, gefitinib had significant radiosensitizing effects on NSCLC cell lines [43]. Gefitinib enhances the radioresponse of NSCLC cells by suppressing cellular DNA repair capacity. But in unselected population, gefitinib did not improve survival [44]. The trial from the National Cancer Institute of Canada Clinical Trials Group showed that erlotinib monotherapy prolonged survival in patients with advanced NSCLC who had progressed after standard chemotherapy [45], and erlotinib is approved in this setting. Interestingly, EGFR expression does not seem to correlate with response to EGFR inhibitors but a recent analysis of data from this trial indicated that EGFR mutations and high copy number are predictive of response to erlotinib [46]. In addition, EGFR fluorescence in situ hybridization score was a significant predictive marker of differential survival benefit from erlotinib. Erlotinib-induced apoptosis was augmented by radiation in very high expression of HER1/ EGFR cells only. In conclusion, high HER1/EGFR expression may result in a high degree of radiosensitization with erlotinib combined with radiation [47]. A strong rationale may exist for combining erlotinib with RT. Erlotinib helps disrupt cell growth pathways and enhances the sensitivity of cells to the effects of RT [48-50]. It is also possible that RT enhances the effectiveness of erlotinib by cytoreducing the tumor and creating a hypoxic environment [51]. Several studies in NSCLC were made to evaluate erlotinib in combination with RT. A prospective phase II study found that RT and concurrent erlotinib used in the treatment of patients with unresectable NSCLC shows promising results without an increase in toxicity [52]. Adverse events related to RT included esophagitis, radiation dermatitis, and pneumonitis. The addition of erlotinib to RT did not appear to increase RT-associated toxicities. Erlotinib-related adverse events included mild to moderate skin rash (61.5\%) and diarrhea (23\%). The RR was $55.5 \%$ in the RTalone arm compared with $83.3 \%$ in the erlotinib arm. The Cancer and Leukemia Group B is conducting a phase II trial, CALGB 30605, of paclitaxel followed by RT and erlotinib in patients with unresectable stage III NSCLC. The study is evaluating induction chemotherapy consisting of paclitaxel and carboplatin. Patients with no disease progression outside the planned radiation field will continue to receive concurrent erlotinib and RT. Results from current studies are eagerly awaited.

Several drugs interfering with the EGFR signaling pathway have been developed e.g. cetuximab (a human-murine chimeric IgG1 monoclonal antibody that binds to the extracellular region of the EGFR). Under experimental laboratory conditions in animal models, cetuximab increases tumour radiocurability (fractionated and single dose irradiation) [53,54]. The feasibility of adding the epidermal growth factor receptor inhibitor cetuximab has been recently reported for NSCLC patients [55]. We found a few phase II clinical trials of cetuximab combined with radiotherapy for non-small cell lung cancer. Two of them have combined RT and cetuximab without any chemotherapy in patients who are not candidates for chemoradiation $[56,57]$. Combined radioimmunotherapy with cetuximab was safe and feasible, especially in elderly patients with multiple comorbidities. Another studies of them included patients with inoperable stage III disease and good performance status after the induction chemotherapy $[58,59]$. Induction chemotherapy followed by concurrent cetuximab and RT to 68 Gy was clearly feasible with promising survival. Toxicity, like pneumonitis and esophagitis was low compared to most schedules with concurrent chemotherapy. The last study has published by Radiation Therapy Oncology Group (RTOG) was a phase II study of chemoradiotherapy with carboplatin and paclitaxel plus cetuximab in patients with stage III NSCLC [60]. The combination of cetuximab with CRT is feasible and shows promising activity. The overall survival achieved with this regimen was longer than any previously reported by the Radiation Therapy Oncology Group with median survival 22.7 months, and 24-month overall survival - $49.3 \%$. The second trial in this category with several important differences (mandatory PET, higher radiation dose of $70 \mathrm{~Gy}$, only 7 weeks of cetuximab concomitant to RT, chemotherapy with carboplatin and pemetrexed) was done [61]. Median survival was 25.2 months and failure-free survival 12.3 months.

Until now no definite data can be reported. Further basic research and appropriately designed clinical studies are clearly needed to optimize scheduling of combined radiation and molecular targeted therapies. The results of the published clinical trials (one of them was a phase III study) suggest that larger randomized trials are warranted. It is very important to include the right patient population especially patients with the right genetics/mutations for these clinical trials.

\section{Conclusions}

Patients with stage III disease differ with regard to primary tumour volume and proximity/infiltration to surrounding structures, extent of lymphatic spread, cancer biology, and host factors such as age, cardiopulmonary function and other comorbidity. Treatment recommendations have to take into account these differences and stratify patients according to technical resectability, ability to tolerate high-dose radiotherapy and chemotherapy, and many more. Many patients with inoperable stage III disease are candidates for combined modality chemo- and radiotherapy (RT). In conclusion after two decades of mainly sequentially combined treatment, concurrent radiochemotherapy is nowadays the standard treatment of locally advanced NSCLC. However, there are some doubts.

Firstly, it should be realized that the trial data were collected in a period before routine staging with FDG-PET and MRI of the brain. The routine use of these tests definitely changes the population of patients enrolled in radiochemotherapy.

Secondly, the other topics for future research are RCT with more sophisticated radiotherapy techniques allowing possibly higher tumour doses and/or lower toxicities in surrounding healthy tissues. For patients with larger tumor volumes, the possibilities to increase the radiation dose were limited by normal tissue constraints (esophagus and spinal cord). Conventionally fractionated radiotherapy for stage I NSCLC has shown inferior outcomes than surgery and these results are linked to insufficient radiation doses. After the impact of RT dose for lung cancer was established, a number of trials were structured in the quest for better local control and overall survival by either dose escalation or shortening the total treatment time through conventional/ altered fractionation, even in combination with chemotherapy. The delivery of 60 Gy resulted in a 5-year survival rate of $38 \%$ for patients with primary tumours less than $2 \mathrm{~cm}$ in size, $22 \%$ for tumours $2-3 \mathrm{~cm}$ in size, $5 \%$ for tumours $3-4 \mathrm{~cm}$ in size, and $0 \%$ for larger tumours [62]. Based on biological and statistical modelling of tumour responses to various radiation dose levels, it has been shown that doses as high as 80 to 90 Gy ensure a progression-free survival rate of 50\% [63]. The majority of studies concluded that patients receiving higher radiation doses have better treatment outcomes $[64,65]$. 
New technical advances in the application of RT enhanced the ability of targeted treatment and sparing of normal tissues, making high BED studies possible. Intensity-modulated radiotherapy (IMRT) has the potential benefit to further increase the dose that can be safely prescribed in lung cancer patients due to a better conformity index [6668]. In Stereotactic Radiation Therapy (SABR), high doses per limited number of fractions are used, although the actual biologically equivalent dose (BED) for the eradication is not yet completely understood [69]. When a sufficient dose (BED $\geq 100 \mathrm{~Gy}$ ) is used, it has been noted in most clinical studies that the success rate of local control is over $90 \%$. In particular, the surprising results of the RTOG 0617 trial [70] drove attention to the importance of adverse effects, once again emphasising that future research should focus on quality of life.

Thirdly, in most of these studies authors have not taken in the analysis factors such as histological type, age, comorbid conditions. Since the incidence of NSCLC is high among elderly patients and many of them have a smoking history, the majority has severe comorbidities. Therefore, aggressive combined modality treatment might be contraindicated or poorly tolerated. However, age is not an independent prognostic factor in stage III and IV NSCLC and epidemiological studies show that, with increasing age, the percentage of people treated with chemotherapy decreases [71-73]. Elderly patients with marginal renal function (creatinine clearance $<70 \mathrm{~mL} / \mathrm{min}$ ) or marginal cardiac function are eligible for administration of daily low-dose cisplatin, while administration of full-dose chemotherapy is often contraindicated. Combination of concurrent daily cisplatin with radiation appears to be a good alternative, especially in these elderly, frail patients $[74,75]$. Also preclinical studies on RCT support the use of daily administration for optimal radiosensitizing effects [76]. This approach, delivered in a short overall treatment time, is suitable for both the elderly and for patients with comorbidities. It also offers the opportunity to combine concomitant radiochemotherapy with new agents. Existing data concerning targeted therapies in conjunction with radiotherapy are inconsistent and do not allow for firm conclusions. The optimal timing of the administration of RT and EGFR kinase inhibitors has yet to be determined. Strategies to safely incorporate novel antiangiogenic agents into combined-modality therapy in lung cancer are needed. The studies using targeted therapies in particular addressing their optimal integration with radiotherapy are still in their infancy. The rapid development of molecular oncology will hopefully contribute to a better patient selection to particular strategies and to treatment optimization.

\section{Appendix}

The information was gathered from extensive PubMed searches (no limits to publication period were applied but only Englishlanguage papers are referenced). Additional references, including congress abstract presentations, are included where appropriate and in particular where there are no published studies on a discussion topic.

\section{References}

1. Ferlay J, Shin HR, Bray F, Forman D, Mathers C, et al. (2010) Estimates of worldwide burden of cancer in 2008: GLOBOCAN 2008. Int J Cancer 127: 2893-2917.

2. Jemal A, Siegel R, Ward E, Murray T, Xu J, et al. (2007) Cancer Statistics, 2007. CA Cancer J Clin 57: 43-66.

3. Perez CA, Stanley K, Grundy G, Hanson W, Rubin P, et al. (1982) Impact of irradiation technique and tumor extent in tumor control and survival of patients with unresectable non-oat cell carcinoma of the lung: report by the Radiation Therapy Oncology Group. Cancer 50: 1091-1099.

4. Saunders MI, Dische S (1990) Continuous, hyperfractionated, accelerated radiotherapy (CHART) in non-small cell carcinoma of the bronchus. Int J Radiat Oncol Biol Phys 19: 1211-1215.

5. Kong FM, Ten Haken RK, Schipper MJ, Sullivan MA, Chen M, et al. (2005) High-dose radiation improved local tumor control and overall survival in patients with inoperable/unresectable non-small-cell lung cancer: long-term results of a radiation dose escalation study. Int J Radiat Oncol Biol Phys 63: 324-333.

6. Wurstbauer K, Weise H, Deutschmann H, Kopp P, Merz F, et al. (2010) Non-small cell lung cancer in stages I-IIIB: Long-term results of definitive radiotherapy with doses $\geq 80 \mathrm{~Gy}$ in standard fractionation. Strahlenther Onkol 186: 551-557.

7. Machtay M, Bae K, Movsas B, Paulus R, Gore EM, et al. (2010) Higher biologically effective dose of radiotherapy is associated with improved outcomes for locally advanced non-small cell lung carcinoma treated with chemoradiation: An analysis of the Radiation Therapy Oncology Group. Int $J$ Radiat Oncol Biol Phys 82: 425-434.

8. Guckenberger M, Wilbert J, Richter A, Baier K, Flentje M (2011) Potential of adaptive radiotherapy to escalate the radiation dose in combined radiochemotherapy for locally advanced non-small cell lung cancer. Int J Radiat Oncol Biol Phys 79: 901-908.

9. De Ruysscher D, Faivre-Finn C, Nestle U, Hurkmans CW, Le Péchoux C et al. (2010) European Organisation for Research and Treatment of Cancer recommendations for planning and delivery of high-dose, high-precision radiotherapy for lung cancer. J Clin Oncol 28: 5301-5310.

10. Dillman RO, Seagren SL, Propert KJ, Guerra J, Eaton WL, et al. (1990) A randomized trial of induction chemotherapy plus high-dose radiation versus radiation alone in stage III non-small-cell lung cancer. N Engl J Med 323: $940-$ 945.

11. [No authors listed] (1995) Chemotherapy in non-small cell lung cancer: a metaanalysis using updated data on individual patients from 52 randomised clinical trials. Non-small Cell Lung Cancer Collaborative Group. BMJ 311: 899-909.

12. Le Chevalier T, Arriagada R, Quoix E, Ruffie P, Martin M, et al. (1991) Radiotherapy alone versus combined chemotherapy and radiotherapy in nonresectable non-small-cell lung cancer: first analysis of a randomized trial in 353 patients. J Natl Cancer Inst 83: 417-423.

13. Jassem J, Begg AC, Stewart F, Bartelink H (1995) Combined chemotherapy and radiotherapy In: Oxford textbook of oncology. Peckham M, Pinedo HM, Veronesi U. (ed.) Oxford University Press, Oxford, 1995: 811-23.

14. Schaake-Koning C, van den Bogaert W, Dalesio O, Festen J, Hoogenhout J, et al. (1992) Effects of concomitant cisplatin and radiotherapy on inoperable nonsmall-cell lung cancer. N Engl J Med 326: 524-530.

15. Trovò MG, Zanelli GD, Minatel E, Franchin G, Gobitti C (1992) Radiotherapy versus radiotherapy enhanced by cisplatin in stage III non-small cell lung cancer. Int J Radiat Oncol Biol Phys 24: 11-15.

16. Aupérin A, Le Péchoux C, Pignon JP, Koning C, Jeremic B, et al. (2006) Concomitant radio-chemotherapy based on platin compounds in patients with locally advanced non-small cell lung cancer (NSCLC): a meta-analysis of individual data from 1764 patients. Ann Oncol 17: 473-483.

17. Rowell NP, O'rourke NP (2004) Concurrent chemoradiotherapy in non-small cell lung cancer. Cochrane Database Syst Rev 18: CD002140.

18. Clamon G, Herndon J, Eaton W, Rosenman J, Maurer LH, et al. (1994) A feasibility study of extended chemotherapy for locally advanced non-small cell lung cancer: a phase II trial of cancer and leukemia group B. Cancer Invest 12: $273-282$.

19. Fournel P, Robinet G, Thomas $P$, Souquet PJ, Léna H, et al. (2005) Randomized phase III trial of sequential chemoradiotherapy compared with concurrent chemoradiotherapy in locally advanced non-small-cell lung cancer: groupe Lyon-Saint-Etienne d'Oncologie Thoracique-Groupe Français de PneumoCancérologie NPC 95-01 Study. J Clin Oncol 23: 5910-5917.

20. Furuse K, Fukuoka M, Kawahara M, Nishikawa H, Takada Y, et al. (1999) Phase III study of concurrent versus sequential thoracic radiotherapy in combination with mitomycin, vindesine, and cisplatin in unresectable stage III non-small-cell lung cancer. J Clin Oncol 17: 2692-2699.

21. Ulutin HC, Güden M, Oysul K, Sürenkök S, Pak Y (2000) Split-course radiotherapy with or without concurrent or sequential chemotherapy in nonsmall cell lung cancer. Radiat Med 18: 93-96.

22. Zatloukal P, Petruzelka L, Zemanova M, Havel L, Janku F, et al. (2004) 
Concurrent versus sequential chemoradiotherapy with cisplatin and vinorelbine in locally advanced non-small cell lung cancer: a randomized study. Lung Cancer 46: 87-98.

23. Belderbos J, Uitterhoeve L, van Zandwijk N, Belderbos $\mathrm{H}$, Rodrigus $\mathrm{P}$, et al. (2007) Randomised trial of sequential versus concurrent chemo-radiotherapy in patients with inoperable non-small cell lung cancer (EORTC 08972-22973). Eur J Cancer 43: 114-121.

24. Aupérin A, Le Péchoux C, Rolland E, Curran WJ, Furuse K, et al. (2010) Meta-analysis of concomitant versus sequential radiochemotherapy in locally advanced non-small-cell lung cancer. J Clin Oncol 28: 2181-2190.

25. O'Rourke N, Roqué I Figuls M, Farré Bernadó N, Macbeth F (2010) Concurrent chemoradiotherapy in non-small cell lung cancer. Cochrane Database Syst Rev : CD002140.

26. Auperin A, Rolland E, Curran W Jr, Stewart L, Ulutin HC, et al. (2007) Concomitant radio-chemotherapy (RT-CT) versus sequential RT-CT in locally advanced non-small cell lung cancer (NSCLC): a meta-analysis using individual patient data (IPD) from randomised clinical trials (RCTs). J Thorac Oncol 69: S5.

27. Robinson LA, Ruckdeschel JC, Wagner H Jr, Stevens CW; American College of Chest Physicians (2007) Treatment of non-small cell lung cancer-stage IIIA ACCP evidence-based clinical practice guidelines (2nd edition). Chest 132: 243S-265S.

28. Jett JR, Schild SE, Keith RL, Kesler KA; American College of Chest Physicians (2007) Treatment of non-small cell lung cancer, stage IIIB: ACCP evidencebased clinical practice guidelines (2nd edition). Chest 132: 266S-276S.

29. Mayor S (2005) NICE issues guidance for diagnosis and treatment of lung cancer. BMJ 330: 439

30. De Ruysscher D, Botterweck A, Dirx M, Pijls-Johannesma M, Wanders R, et al. (2009) Eligibility for concurrent chemotherapy and radiotherapy of locally advanced lung cancer patients: a prospective, population-based study. Ann Oncol 20: 98-102.

31. El Sharouni SY, Kal HB, Battermann JJ (2003) Accelerated regrowth of nonsmall-cell lung tumours after induction chemotherapy. Br J Cancer 89: 2184 2189 .

32. Chen CP, Weinberg VK, Jahan TM, Jablons DM, Yom SS (2011) Implications of delayed initiation of radiotherapy: accelerated repopulation after induction chemotherapy for stage III non-small cell lung cancer. J Thorac Oncol 6: 18571864.

33. Machtay M, Hsu C, Komaki R, Sause WT, Swann RS, et al. (2005) Effect of overall treatment time on outcomes after concurrent chemoradiation for locally advanced non-small-cell lung carcinoma: analysis of the Radiation Therapy Oncology Group (RTOG) experience. Int J Radiat Oncol Biol Phys 63: 667-671.

34. Hanna NN, Seetharam S, Mauceri HJ, Beckett MA, Jaskowiak NT, et al. (2000) Antitumor interaction of short-course endostatin and ionizing radiation. Cancer J 6: 287-293.

35. Dings RP, Williams BW, Song CW, Griffioen AW, Mayo KH, et al. (2005) Anginex synergizes with radiation therapy to inhibit tumor growth by radiosensitizing endothelial cells. Int J Cancer 115: 312-319.

36. Citrin D, Ménard C, Camphausen K (2006) Combining radiotherapy and angiogenesis inhibitors: clinical trial design. Int J Radiat Oncol Biol Phys 64: $15-25$

37. Fogarty M (2002) Learning from angiogenesis trial failures. The Scientist 16 : 33-35.

38. Gorski DH, Beckett MA, Jaskowiak NT, Calvin DP, Mauceri HJ, et al. (1999) Blockage of the vascular endothelial growth factor stress response increases the antitumor effects of ionizing radiation. Cancer Res 59: 3374-3378.

39. Abdollahi A, Lipson KE, Sckell A, Zieher H, Klenke F, et al. (2003) Combined therapy with direct and indirect angiogenesis inhibition results in enhanced antiangiogenic and antitumor effects. Cancer Res 63: 8890-8898.

40. Winkler F, Kozin SV, Tong RT, Chae SS, Booth MF, et al. (2004) Kinetics of vascular normalization by VEGFR2 blockade governs brain tumor response to radiation: role of oxygenation, angiopoietin-, and matrix metalloproteinases. Cancer Cell 6: 553-563

41. Spigel DR, Hainsworth JD, Yardley DA, Raefsky E, Patton J, et al. (2010) Tracheoesophageal fistula formation in patients with lung cancer treated with chemoradiation and bevacizumab. J Clin Oncol 28: 43-48.
42. Socinski MA, Stinchcombe TE, Moore DT, Gettinger SN, Decker RH, et al (2012) Incorporating bevacizumab and erlotinib in the combined-modality treatment of stage III non-small-cell lung cancer: results of a phase I/II trial. J Clin Oncol 30: 3953-3959.

43. Tanaka T, Munshi A, Brooks C, Liu J, Hobbs ML, et al. (2008) Gefitinib radiosensitizes non-small cell lung cancer cells by suppressing cellular DNA repair capacity. Clin Cancer Res 14: 1266-1273.

44. Kelly K, Chansky K, Gaspar LE, Albain KS, Jett J, et al. (2008) Phase III trial of maintenance gefitinib or placebo after concurrent chemoradiotherapy and docetaxel consolidation in inoperable stage III non-small-cell lung cancer SWOG S0023. J Clin Oncol 26: 2450-2456.

45. Shepherd FA, Rodrigues Pereira J, Ciuleanu T, Tan EH, Hirsh V, et al. (2005) National Cancer Institute of Canada Clinical Trials Group. Erlotinib in previously treated non-small-cell lung cancer. N Engl J Med 353: 123-132.

46. Zhu CQ, da Cunha Santos G, Ding K, Sakurada A, Cutz JC, et al. (2008) Role of KRAS and EGFR as biomarkers of response to erlotinib in National Cance Institute of Canada Clinical Trials Group Study BR.21. J Clin Oncol 26: 42684275.

47. Kim JC, Ali MA, Nandi A, Mukhopadhyay P, Choy H, et al. (2005) Correlation of HER1/EGFR expression and degree of radiosensitizing effect of the HER1/ EGFR-tyrosine kinase inhibitor erlotinib. Indian J Biochem Biophys 42: 358 365

48. Chinnaiyan P, Huang S, Vallabhaneni G, Armstrong E, Varambally S, et al (2005) Mechanisms of enhanced radiation response following epidermal growth factor receptor signaling inhibition by erlotinib (Tarceva). Cancer Res 65: 3328-3335.

49. Nyati MK, Morgan MA, Feng FY, Lawrence TS (2006) Integration of EGFR inhibitors with radiochemotherapy. Nat Rev Cancer 6: 876-885.

50. Baumann M, Krause M, Dikomey E, Dittmann K, Dörr W, et al. (2007) EGFR-targeted anti-cancer drugs in radiotherapy: preclinical evaluation of mechanisms. Radiother Oncol 83: 238-248.

51. Tortora G, Gelardi T, Ciardiello F, Bianco R (2007) The rationale for the combination of selective EGFR inhibitors with cytotoxic drugs and radiotherapy. Int J Biol Markers 22: S47-52.

52. Martinez E, Martinez M, Viñolas N, Casas F, de la Torre A, et al. (2008) Feasibility and tolerability of the addition of erlotinib to 3D thoracic radiotherapy (RT) in patients $(p)$ with unresectable NSCLC: a prospective randomized phase II study. J Clin Oncol 26: 7563.

53. Milas L, Fan Z, Andratschke NH, Ang KK (2004) Epidermal growth factor receptor and tumor response to radiation: in vivo preclinical studies. Int J Radiat Oncol Biol Phys 58: 966-971.

54. Nasu S, Ang KK, Fan Z, Milas L (2001) C225 antiepidermal growth factor receptor antibody enhances tumor radiocurability. Int J Radiat Oncol Biol Phys 51: 474-477.

55. Govindan R, Bogart J, Stinchcombe T, Wang X, Hodgson L, et al. (2011) Randomized phase II study of pemetrexed, carboplatin, and thoracic radiation with or without cetuximab in patients with locally advanced unresectable nonsmall-cell lung cancer: Cancer and Leukemia Group B trial 30407. J Clin Oncol 29: 3120-3125.

56. Jatoi A, Schild SE, Foster N, Henning GT, Dornfeld KJ, et al. (2010) A phase II study of cetuximab and radiation in elderly and/or poor performance status patients with locally advanced non-small-cell lung cancer (N0422). Ann Oncol 21: $2040-2044$.

57. Jensen $A D$, Münter MW, Bischoff HG, Haselmann R, Haberkorn $U$, et al (2011) Combined treatment of nonsmall cell lung cancer NSCLC stage III with intensity-modulated RT radiotherapy and cetuximab: the NEAR trial. Cancer 117: 2986-2994.

58. Hallqvist A, Wagenius G, Rylander H, Brodin O, Holmberg E, et al. (2011) Concurrent cetuximab and radiotherapy after docetaxel-cisplatin induction chemotherapy in stage III NSCLC: Satellite - A phase II study from the Swedish Lung Cancer Study Group. Lung Cancer 71: 166-172.

59. Hughes S, Liong J, Miah A, Ahmad S, Leslie M, et al. (2008) A brief report on the safety study of induction chemotherapy followed by synchronous radiotherapy and cetuximab in stage III non-small cell lung cancer (NSCLC) SCRATCH study. J Thorac Oncol 3: 648-651.

60. Blumenschein GR Jr, Paulus R, Curran WJ, Robert F, Fossella F, et al. (2011) 
Citation: Adamowicz K (2015) Combining Systemic Therapies with Radiation in Non-Small Cell Lung Cancer. J Cancer Sci Ther 7: 102-110. doi:10.4172/1948-5956.1000332

Phase II study of cetuximab in combination with chemoradiation in patients with stage IIIA/B non-small-cell lung cancer: RTOG 0324. J Clin Oncol 29: 23122318.

61. Govindan R, Bogart J, Stinchcombe T, Wang X, Hodgson L, et al. (2011) Randomized phase II study of pemetrexed, carboplatin, and thoracic radiation with or without cetuximab in patients with locally advanced unresectable nonsmall-cell lung cancer: Cancer and Leukemia Group B Trial 30407. J Clin Oncol 29: 3120-3125.

62. Noordijk EM, vd Poest Clement E, Hermans J, Wever AM, Leer JW (1988) Radiotherapy as an alternative to surgery in elderly patients with resectable lung cancer. Radiother Oncol 13: 83-89.

63. Onishi H, Shirato H, Nagata Y, Hiraoka M, Fujino M, et al. (2007) Hypofractionated stereotactic radiotherapy (HypoFXSRT) for stage I nonsmall cell lung cancer: updated results of 257 patients in a Japanese multiinstitutional study. J Thorac Oncol 2: 94-100.

64. Sibley GS (1998) Radiotherapy for patients with medically inoperablestage I nonsmall cell lung carcinoma: smaller volumes and higherdoses-a review. Cancer 82: 433-438.

65. Timmerman R, Paulus R, Galvin J, Michalski J, Straube W, et al. (2010) Stereotactic body radiation therapy for inoperable early stage lung cancer. JAMA 303: 1070-1076.

66. Grills IS, Yan D, Martinez AA, Vicini FA, Wong JW, et al. (2003) Potential for reduced toxicity and dose escalation in the treatment of inoperable non-smallcell lung cancer: a comparison of intensity-modulated radiation therapy (IMRT) 3D conformal radiation, and elective nodal irradiation. Int J Radiat Oncol Biol Phys 57: 875-890.

67. Murshed H, Liu HH, Liao Z, Barker JL, Wang X, et al. (2004) Dose and volume reduction for normal lung using intensity-modulated radiotherapy for advancedstage non-small-cell lung cancer. Int J Radiat Oncol Biol Phys 58: 1258-1267.

68. Schwarz M, Alber M, Lebesque JV, Mijnheer BJ, Damen EMF (2005) Dose heterogeneity in the target volume and intensity-modulated radiotherapy to escalate the dose in the treatment of non-small-cell lung cancer. Int J Radiat Oncol Biol Phys 62: 561-570.

69. Park C, Papiez L, Zhang S, Story M, Timmerman RD (2008) Universal survival curve and single fraction equivalent dose: useful tools in understanding potency of ablative radiotherapy. Int J Radiat Oncol Biol Phys 70: 847-852.

70. Bradley JD, Paulus R, Komaki R, Masters G, Forster K, et al. (2011) Standard-dose versus high-dose conformal radiotherapy with concurrent and consolidation carboplatin plus paclitaxel with or without cetuximab for patients with stage IIIA or IIIB non-small-cell lung cancer (RTOG 0617): a randomised, two-by-two factorial phase 3 study. Lancet Oncol 16: 187-199.

71. Janssen-Heijnen ML, Smulders S, Lemmens VE, Smeenk FW, van Geffen HJ, et al. (2004) Effect of comorbidity on the treatment and prognosis of elderly patients with non-small cell lung cancer. Thorax 59: 602-607.

72. Pignon T, Gregor A, Schaake Koning C, Roussel A, Van Glabbeke M, et al. (1998) Age has no impact on acute and late toxicity of curative thoracic radiotherapy. Radiother Oncol 46: 239-248.

73. Socinski MA (2004) Clinical issues in the management of non-small-cell lung cancer and the role of platinum-based therapy. Clin Lung Cancer 5: 274-289.

74. Takata I, Ueoka H, Kiura K, Tabata M, Takigawa N, et al. (2002) Daily lowdose cisplatin and concurrent thoracic irradiation for poor-risk patients with unresectable non-small-cell lung cancer. Acta Med Okayama 56: 261-266.

75. Uitterhoeve AL, Koolen MG, van Os RM, Koedooder K, van de Kar M, et al (2007) Accelerated high-dose radiotherapy alone or combined with either concomitant or sequential chemotherapy; treatments of choice in patients with Non-Small Cell Lung Cancer. Radiat Oncol 2: 27.

76. Bartelink H, Kallman RF, Rapacchietta D, Hart GA (1986) Therapeutic enhancement in mice by clinically relevant dose and fractionation schedules of cis-diamminedichloroplatinum (II) and irradiation. Radiother Oncol 6: 61-74. 